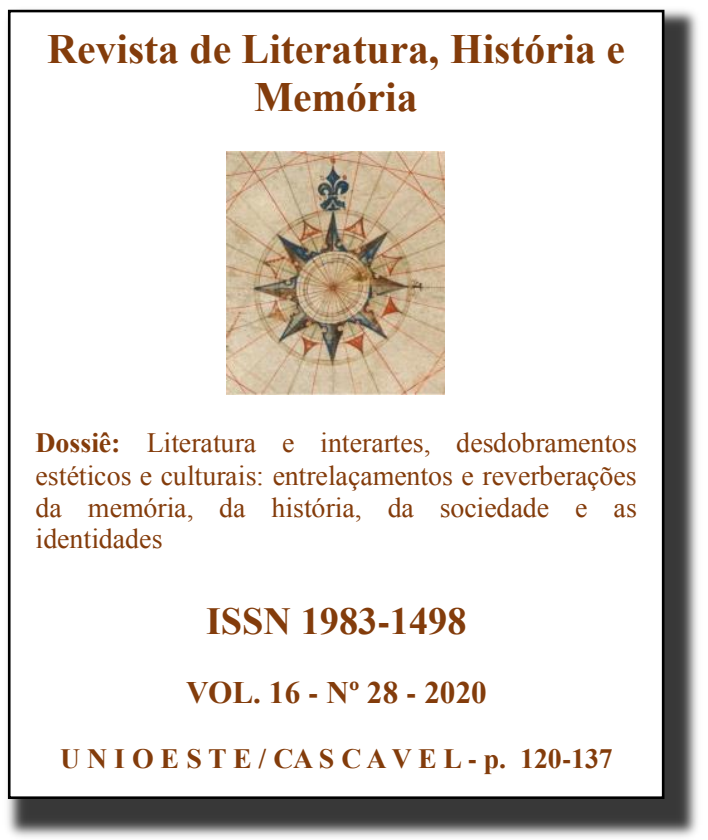

\title{
MODA E MODOS: A INFLUÊNCIA DOS SAPATOS NO COMPORTAMENTO DAS PERSONAGENS INÊS E SABRINA EM SAPATO DE SALTO DE LYGIA BOJUNGA
}

Fashion and manners: the influence of shoes on the behavior of the characters Inês and Sabrina in Sapato de salto of Lygia Bojunga

Danielle da Silva Apolinario ${ }^{1}$

RESUMO: O presente artigo analisa as personagens Inês e Sabrina na obra Sapato de salto, da escritora brasileira Lygia Bojunga, e busca, por meio dos elementos da moda que as calça, apontar como esses artefatos, muitas vezes impostos às mulheres, são apresentados no enredo. A escritora questiona na narrativa os valores defendidos pela sociedade patriarcal, propiciando aos jovens leitores espaço para a revisão de suas crenças e atitudes, que se refletem na aparência física exibida por homens e mulheres. As discussões deste artigo, portanto, englobam questões presentes no cotidiano da sociedade e, por conseguinte, do ambiente escolar - lugar em que circulam obras literárias de Bojunga e onde as diversidades são, muitas vezes, negligenciadas em detrimento da padronização dos corpos e dos comportamentos. Para a investigação do tema proposto, a pesquisa assume caráter qualitativo, de cunho exploratório, cuja coleta de dados possui foco na pesquisa bibliográfica. $\mathrm{O}$ aporte teórico norteador da análise se baseia nas pesquisas de Linda O'Keeffe (2008) e Rachelle Bergstein (2013).

PALAVRAS-CHAVE: Lygia Bojunga - Sapato de salto; Literatura infanto-juvenil; Personagens femininas; Modos e Moda.

ABSTRACT: The article analyses the characters Inês and Sabrina from the work Sapato de salto, written by the Brazilian author Lygia Bojunga. In plot the author suggests that the fashion elements worn by them are artifacts imposed to woman. The writer questions the values defended by the patriarchal society, which provides to young readers room for reflection for their beliefs and attitudes that mirrors the physical appearance exhibited by man and woman. The considerations embrace questions that are part of the daily life, including the school environment - place in which Bojunga's literary works circulate, and where also diversity is disregarded to the detriment of bodies and behaviors standardization. To allow this investigation, we propose a qualitative and exploratory research, which emphasis is the bibliographical research. We based our analysis in the theoretical basis present on the works of Linda O'Keeffe (2008) and Rachelle Bergstein (2013).

KEY-WORDS: Lygia Bojunga - Sapato de salto; Youth literature; Female character; Fashion and Manners.

\footnotetext{
1 Mestra em Letras pela Universidade Federal do Espírito Santo (UFES). Pós-Graduada (Lato Sensu) em Educação Profissional Integrada à Educação Básica na Modalidade de Educação de Jovens e Adultos, pelo Instituto Federal do Espírito Santo - Ifes. Licenciada em Letras Português. Professora da educação básica pela Prefeitura de Vila Velha e pelo Governo do Estado do Espírito Santo (SEDU).
} 


\section{INTRODUÇÃO}

Os debates sobre as relações de gênero nos possibilitam reflexionar sobre o patriarcado, a misoginia, a violência e a hostilidade contra a mulher e contra o que diz respeito ao mundo feminino. Oportunizam, ainda, repensar os discursos que validam as relações de poder, desvalorizam, em algumas circunstâncias, o que se considera ser atributo de mulher, enquanto o que se estabelece como masculinidade conserva-se seguro e superior.

Simone de Beauvoir (1970), em sua obra Segundo Sexo: fatos e mitos, já advertia que os experts temiam a carência da feminilidade e incentivaram os seres nascidos com útero a serem mulheres, visto que, nas palavras da autora: “todo ser humano do sexo feminino não é, portanto, necessariamente mulher; cumpre-lhe participar dessa realidade misteriosa e ameaçada que é a feminilidade" (BEAUVOIR, 1970, p. 7) e acrescentava: "será esta secretada pelos ovários? Ou estará congelada no fundo de um céu platônico? E bastará uma saia rugeruge para fazê-la descer à terra?" (BEAUVOIR, 1970, p.7).

O raciocínio de Beauvoir (1970) leva a concluir que, embora a ideia de que há uma feminilidade inerente à mulher contribua para pautar, por vezes, os ditames da moda, não existe uma feminilidade que venha com a mulher quando ela nasce; mas sim, que se incorpora a ela por meio de processos de construção dessa feminilidade que são sociais e definidos cultural e historicamente desde muito cedo. Incutidas nesse processo estão as regras de como se vestir, como se adornar e como se calçar, que também fazem parte da construção social do que é ser mulher e feminina.

De acordo com esse viés, examinamos, pois, as personagens Inês e Sabrina na obra Sapato de salto da escritora brasileira Lygia Bojunga, mais especificamente no tocante aos sapatos utilizados por essas mulheres ao longo da trama. Identificamos como a moda, por meio do calçado, faz parte da construção narrativa e reflete os comportamentos dessas mulheres. Discutimos, ainda, como as arbitrariedades e as imposições nos modos de calçar são muitas vezes danosas à saúde física e psicológica das mulheres, embora, por outro lado, reconhecemos que há possíveis objeções desse ser feminino diante de tais injunções.

Estão moda e modos amarrados, costurados, tecidos; e juntos se aderem às mulheres, cuja obrigatoriedade nos tipos de vestuários, de adornos e de sapatos, culminam em situações sofríveis, dificultando andar, entrar, sair, mover-se em seus diversos contextos sociais. Contudo, esses imperativos não impediram que alguns grupos de mulheres usassem, dentre outras ferramentas, peças do vestuário como arma para os enfrentamentos, as resistências e as demonstrações do desejo de mudança. Exemplificam essa oposição, no século XIX, as 
sufragistas e os diversos membros de movimentos feministas que procuravam maneiras de tornar o vestuário feminino mais funcional e confortável, seguidas das flappers, como eram chamadas as moças estadunidenses que vestiam saias curtas, aboliram o espartilho e desafiavam a conduta feminina imposta na época.

Bojunga produz especialmente literatura infanto-juvenil e questiona em suas narrativas os valores impostos pela sociedade patriarcal, propiciando aos jovens leitores o espaço para revisão de crenças e atitudes. As discussões deste artigo, portanto, englobam questões presentes no cotidiano da sociedade e, por conseguinte, do ambiente escolar - lugar em que circulam obras literárias de Bojunga e onde as diversidades são, muitas vezes, negligenciadas em detrimento da padronização dos corpos e dos comportamentos. Debater sobre a moda, usando como suporte a literatura feita para crianças e jovens, implica abordar essa desatenção do âmbito escolar, uma vez que a moda - vestuário, adornos, sapatos, penteados - condiciona o nosso modo de ser e de estar no mundo.

\section{VESTUÁRIO: A COMPOSIÇÃO COMPLETA}

Quando usados por nossos ancestrais, os calçados objetivavam cobrir os pés, destinavam-se à proteção contra possíveis danos causados pelo caminhar cotidiano e "devido à simplicidade da sua construção, não é de admirar que as sandálias tenham sido o primeiro calçado feito pelo homem, sucedendo as primitivas peles de animais enroladas à volta dos pés" (O’KEEFFE, 2008, p. 22). Aquele calçado foi uma inspiração, tendo em vista que "cada civilização antiga terá criado a sua própria versão do modelo base: uma sola rija, presa ao pé com correias" (O’KEEFFE, 2008, p. 22).

A partir da dimensão estética exigida para compor o traje é que o vestuário, principalmente em relação às mulheres, passa a estar incompleto na ausência desta peça que o define: o calçado. Vestir-se implica adornar também com prioridade os pés. Na cultura grega, "Afrodite, a deusa [...] do amor, era frequentemente representada nua, apenas com um par de sandálias nos pés" (O’KEEFFE, 2008, p. 43). O conto Os sapatinhos vermelhos, de Hans Cristian Andersen (1849), descreve uma cena em que uma Rainha exibe sua filhinha para o povo "num luxuoso vestido branco [...]. Não tinha ela vestido de cauda, nem coroa de ouro na cabeça; mas calçava lindos sapatos vermelhos, de marroquim” (ANDERSEN, 1849) que acabam por aguçar - na personagem protagonista que os vê - o desejo de possuir um par idêntico.

Segundo Rachelle Bergstein (2013), se indagarmos a uma mulher qual é o motivo de 
ela amar sapatos, a resposta será que, além de fazê-la sentir-se bem e serem bonitos, "têm a capacidade de transformar uma roupa de simples jeans e camiseta em um conjunto espetacular de parar o trânsito" (BERGSTEIN, 2013, p. 08); condição que reafirma a relevância desse elemento para a composição do vestuário. Entendemos, pois, que a despeito de sua serventia inicial: proteção dos pés e auxílio da locomoção; o calçado, com o tempo e as mudanças nas demandas sociais, suplantou sua usabilidade primeira e passou a desempenhar o papel de ornamento, moldado pela moda. O cenário contemporâneo é marcado pela diversidade dos calçados que além de possuírem função social, vinculam-se a questões históricas e políticas.

\section{SAPATO DE SALTO: O LIVRO}

A obra Sapato de Salto, da escritora brasileira Lygia Bojunga, narra a história de Sabrina, uma garota abandonada, logo após o nascimento, pela mãe adolescente. A criança permanece em um orfanato e aos dez anos é levada para a residência de um casal, onde passa a trabalhar como babá em troca de "casa, comida, roupa e calçado" (BOJUNGA, 2011, p. 12), além de sofrer abusos diversos e de onde é resgatada por sua tia Inês, até então desconhecida.

A trajetória de Sabrina se entrelaça com a das demais personagens do enredo, sobretudo, sua tia Inês. A trama está composta de constantes conflitos sexuais, amorosos, econômicos e familiares, trazendo à tona a possibilidade da discussão das relações de gênero na sociedade brasileira. Neste artigo, analisamos especificamente duas personagens, Sabrina e Inês. Olhamos para elas de baixo para o alto, interpretando-as a partir da observação da moda no modo de calçar dessas duas mulheres.

\section{UNS SALTOS NA LITERATURA}

A primeira aparição do salto da personagem tia Inês na obra Sapato de Salto de Lygia Bojunga (2011), é descrita pelos olhos da sobrinha, que olha "pro branco apertado da saia [...] e pra perna morena e forte, que descansava o pé num sapato de salto. Bem alto" (BOJUNGA 2011, p. 29-30) evidenciando-se a peça principal na composição do vestuário de Inês: o sapato de salto.

O uso do verbo "descansar", na observação de Sabrina, denota o conforto que tia Inês aparenta sentir sobre o salto alto, aliás, há uma ênfase para ressaltar ser o salto "bem alto" (BOJUNGA 2011, p. 30) que parece não incomodar a personagem que o usa. O Minidicionário Gama Kury da Língua Portuguesa (2001) define o vocábulo descansar, dentre 
outras acepções, como "Apoiar, assentar sobre alguma coisa, repousar do cansaço, tranquilizar, acalmar" (KURY, 2001, p. 231). A perna morena apenas usa os pés - que sugerem estar confortáveis nos sapatos - para apoiá-la enquanto relaxa, repousa.

Podemos nos indagar a respeito desse descanso, uma vez que, permanecer sobre saltos altos, principalmente por longos períodos, é extremamente desconfortável; contudo, a atitude da personagem Inês deixa perceber como os pés femininos podem ser, quiçá, em certas circunstâncias, alvos da dissimulação em busca de atender a uma imposição de normas sociais de feminilidade.

No livro infantil O fantástico mistério de Feiurinha, de Pedro Bandeira (2009), ao se reunirem as princesas de vários contos de fadas em torno de uma solução para o caso do sumiço de Feiurinha, quem chegou primeiro ao encontro no palácio "foi Dona Cinderela Encantada, entrou mancando e logo procurou uma cadeira. Tirou os sapatos e soltou um uf de alívio, enquanto mexia os dedinhos dos pés para reavivar-lhes a circulação" (BANDEIRA, 2009, p.15), sensação que vai na contramão desse possível prazer no uso do salto.

Outras personagens da literatura - talvez menos conhecidas - já foram cúmplices dos flagelos impostos pelo uso do salto alto. Marilena Soneghet dá voz a uma narradora na crônica "Tertúlia", que rememora:

\begin{abstract}
Nos meus tempos de mocinha, a tortura eram os saltos agulha, muito altos, em sapatos de bico fino (elegantérrimos!). Para que todos os artelhos coubessem era preciso que o pai-de-todos montasse sobre o dedão e achatasse o seu vizinho. $\mathrm{O}$ mindinho. Coitado, esse desaparecia retorcido por baixo de todos; logo ele, o mais pequenininho e tão sem expressão - e tudo isso após os pés terem sido cuidadosamente lavados, untados, de creme, cutículas eliminadas, unhas cortadas e lixadas e embelezadas com esmalte escolhido entre as mais belas cores da moda: pêssego, mandarim, crepúsculo... Tudo isso, mais a fina meia de seda, era empurrado no agudo triângulo da biqueira do sapato. Após quatro, cinco horas quando os pés eram finalmente tirados de sua camisa de força (já antes de entrar em casa), era insuportável o latejar, o ver estrelas, o manquejar sofrido, o escalda-pés para aliviar - aah!... (SONEGHET, 2012, p. 42).
\end{abstract}

A narradora descreve minuciosamente o ritual anterior à festividade dos bailes. Os muitos cuidados necessários, esse trato tão meticuloso com os pés, quem sabe, anuncie o padecimento a que serão submetidos nas próximas horas, pois precisam permanecer firmes, fortes, apertados nesse símbolo de elegância feminina, até a hora de se verem desobrigados desse compromisso.

Outra narrativa que recria o sofrimento enfrentado pelas mulheres quando se encontram elegantes sobre seus saltos é a ficção de Sylvia Orthof (2013): Uxa, ora fada, ora 
bruxa. A obra traz a personagem Uxa, uma fada-bruxa que oscila entre o bom e o mau humor. A história é construída a partir de uma relação intertextual com o Conto de Fadas Cinderela. A protagonista se envolve em uma aventura para chegar ao castelo do príncipe onde pretende deixar "cair" seu sapatinho de cristal.

Ao chegar a seu destino, depois de algumas peripécias "Uxa vai subindo a escada, muito dengosamente fada. Aí, chegando no terceiro degrau, senta e pensa: será que eu quero mesmo deixar cair o meu sapatinho de cristal?" (ORTHOF, 2013, p. 22). Nesse instante, eis que "aparece o príncipe, assim, descendo a escada. Olha pra Uxa e diz: - Sou um príncipe feliz. Que belo sapatinho tem esta linda fada!” (ORTHOF, 2013, p. 23). Com a abordagem da alteza,

Uxa leva um susto e sai correndo. Larga os dois sapatos de cristal, que já estão doendo (quer dizer: os pés é que doíam, os sapatos apertavam). E Uxa corre, com medo de virar princesa e ter que ser feliz pra sempre, credo, e vira bruxa, num de repente [...] (ORTHOF, 2013, p. 24).

Travestida de fada, “[...] ela se veste assim: vestido de cetim, varinha de condão, peruca escandinava (que é uma peruca muito loura [...])" (ORTHOF, 2013, p. 09) Uxa estaria prestes a contrair matrimônio, foi galanteada pelo príncipe, mas diante das tantas dúvidas acerca do casamento, a fadinha entende que a solução é se transformar em bruxa: "Uf, que alívio é virar bruxa! Uxa muda de vestido, coloca outro, bem folgado... pois Uxa já correu tanto, parece que criou asa, e já está mudando de roupa em sua casa" (ORTHOF, 2013, p. 25). A fuga do casamento ocorre exatamente ao se travestir de bruxa, mas é o vestido escolhido, bem folgado, que deve garantir o afastamento do príncipe, pois assim, nesses trajes largos, a protagonista sugere apropriar-se de tais artifícios para evitar o aguçamento do desejo daquele que ela não quer mais seduzir.

Observamos, então, como "os sapatos são um paradoxo [...] 'podendo fazer uma mulher se sentir mais ou menos poderosa"” (O’KEEFFE, 2008, p. 72), ao usá-los por um longo período podem desencadear dores e deformações nos pés, porém ao serem usados "para provocar efeito, como os sapatinhos de vidro da Gata Borralheira, podem fazer maravilhas e conceder às suas possuidoras o poder de sedução" (O'KEEFFE, 2008, p. 72), como é o caso de Inês.

Ao contrário do sofrimento seguido de alívio ao descalçar os pés das personagens de Bandeira (2009), de Soneghet (2012) e de Orthof (2013), tia Inês se mostra dona de uma postura segura no alto daqueles saltos, compreende sua posição e - mesmo que ceda aos 
caprichos das normas sociais acerca da feminilidade - ela reafirma a superioridade por meio de suas ações no decorrer do episódio, quando a dona da casa onde Sabrina estava tenta ignorar, sem sucesso, a solicitação da tia de restituir a menina ao lar biológico; Inês apresenta determinação na busca de reestruturar sua família e, consequentemente, sai dali muito confortável sobre o salto, levando junto a sobrinha.

A apresentação suntuosa de Inês está bastante relacionada ao uso do seu calçado, do seu salto, tendo em vista que no cotidiano percebemos que "as mulheres podem 'enfiar' uns chinelos, 'calçar' uns tênis ou 'por' uns sapatos mais confortáveis, mas 'vestem-se' de saltos altos" (O’KEEFFE, 2008, p. 72). Prova disso são as festas de casamento, as premiações do Oscar, os bailes elegantes, lugares cujos trajes, pré-estabelecidos, exigem das mulheres sobretudo das que terão mais visibilidade - além de vestidos luxuosos, penteados e adornos deslumbrantes, o uso de saltos muito altos, mesmo que estes permaneçam entrevistos sob o comprimento da indumentária ou sejam até abandonados no decorrer da cerimônia em um momento menos formal.

\section{OS SALTOS DAS MEMÓRIAS}

Com tia e sobrinha vivendo juntas, o salto reaparece num episódio da narrativa no instante em que Inês recebe em sua casa o menino Andrea Doria com o intuito de ensiná-lo a dançar:

- Posso tirar o sapato? - ele pediu.

- Se você prefere...

- É que tudo que eu gosto de fazer eu gosto de fazer de pé no chão.

A tia Inês riu:

- Pois eu não sou assim: pra cada coisa que eu gosto o meu pé quer um salto diferente. (BOJUNGA, 2011, p. 85).

Andrea Doria, ao afirmar gostar de fazer tudo com os pés no chão, provoca o riso em Inês. Ela ri, pois, ao contrário dele, estima usar sapato para fazer tudo o de que gosta. Porém, é o pé dela que deseja, para cada atividade, variar o salto. Uma espécie de personificação dessa parte do corpo tão valorizada por ela que chega a dar-lhe vida, humanizá-la.

Outro uso figurativo do pé em textos ficcionais está no conto Cinderela do escritor francês Charles Perrault - de domínio público - e com diversas versões adaptadas para livros infantis e audiovisuais. A narrativa francesa compõe a indumentária da protagonista com um precioso sapatinho de cristal; ao badalar da meia noite, com a pressa de regressar a sua casa, para que não se quebrasse o feitiço perante seu príncipe, Cinderela "perde" a peça que, 
posteriormente, é encontrada pela alteza com quem flertava. Nos trechos que se seguem, o rapaz vai em busca de sua amada da noite do baile, no entanto só poderia reconhecê-la mediante o calçar do sapato e não pelas feições de seu rosto, transformando o pé na representação do todo, ele deseja encontrar "um pé que caiba naquele sapato" - uma metonímia da mulher por quem supõe estar apaixonado.

Somado ao uso no sentido figurado, o salto atravessa a narrativa de Bojunga (2011) presente nas formas diferentes de lembranças da personagem Inês que, sozinha no quarto, passa a recordar seu primeiro sapato de salto. Insone, a mulher se mantém "lembrando-elembrando de tudo que tinha contado. Mas lembrando, sobretudo, do que não tinha contado" (BOJUNGA, 2011, p. 120) para a sobrinha em uma conversa entre as duas. Na escuridão do quarto, desperta, tia Inês, "de olho aberto, via passar [...] cena atrás de cena do passado, intercaladas sempre pela mesma imagem: o primeiro sapato de salto que ela comprou pra usar. Preto. De verniz. Salto bem alto" (BOJUNGA, 2011, p. 120), quando ainda era bem jovem. Um sapato estilo fetiche cujos "saltos muito altos impedem os movimentos - uma forma de submissão feminina que há quem ache erótica" (O'KEEFFE, 2008, p. 404). A respeito desse tipo de salto destacamos que "o fetichista ocidental clássico prefere brilhantes sapatos pretos de verniz (que dão ar 'molhado'), longos saltos agulha (associados a mulheres sexualmente agressivas) [...]" (O’KEEFFE, 2008, p. 403). Além disso, "a sua configuração semelhante a uma arma branca excita o homem passivo que sente enorme prazer em ser ameaçado" (O’KEEFFE, 2008, p. 404). O que se revela muito apropriado considerando a profíssão da personagem Inês.

É importante frisar que a cultura de cada sociedade possui uma maneira particular de representar os sapatos que ultrapassa a função utilitária para exprimir estrato social, poder, sedução, fetiche. Segundo o Dicionário de termos de psicanálise de Freud, de Jurema Alcides Cunha (1970), “a quase-reverência fetíchica pelo pé e sapato femininos parece considerar o pé apenas como um símbolo substitutivo para o membro da mulher, uma vez venerado e do qual, desde então, sente a falta" (CUNHA 1970, p. 76-77). A personagem Inês se caracteriza, sobretudo, pela sedução apoiada em seus saltos, muito altos e alguns bastante finos, tal qual os descritos por Linda O'Keeffe (2008), que descreve que a despeito de serem gerados em culturas distintas "os sapatos fetiche ocidentais e os minúsculos sapatos de Lótus da China, [...], transformam quem os usa num objeto e aguçam o apetite sexual de quem os olha" (O'KEEFFE, 2008, p. 402). Porém, a representação do sapato fetiche é mais agressiva, remete a uma arma branca, enquanto o sapato chinês lembra mais uma lingerie. De acordo com a autora: 
[...] os amantes de sapatos existem já desde a antiguidade, mas o fetichismo só surgiria realmente com o nome que tem hoje, na Inglaterra do século XIX. A repressão e o puritanismo vitorianos geraram novos escapes para a expressão sexual. A campanha para esconder as pernas femininas debaixo de saias até o chão e botas de cano foi tão eficaz que o simples vislumbre de um tornozelo de mulher era suficiente para causar excitação sexual. Os tornozelos femininos, e por extensão os sapatos e as botas, tornaram-se símbolos de outras partes do corpo mais escondidas, sendo considerado o desejo e as fantasias desencadeadas pelos pés ou pelo calçado algo absolutamente tabu. Não é de admirar, portanto, que, por volta de 1850 , florescesse em Londres um mercado clandestino de pornografia e sapatos com saltos de $15 \mathrm{~cm}$ (O'KEEFFE, 2008, p. 402-403).

Os sapatos para Inês exprimem a relação paradoxal dessa mulher submissa à volúpia de seu explorador refletida no uso massacrante dos saltos muito altos com o seu próprio desejo, já que ainda muito jovem, quando morava com a mãe, dona Gracinha, a moça compra o seu primeiro par do calçado com as economias que "foi juntando e um dia comprou o sapato de verniz" (BOJUNGA, 2011, p. 120), e em poder dessa peça “entrou em casa feliz da vida, já de verniz no pé. Exibiu o sapato em passo de dança" (BOJUNGA, 2011, p. 120). Mesmo sob as advertências de dona Gracinha a respeito do uso de um salto tão alto, sentia-se feliz e realizada com a aquisição.

Tratar o sapato como investimento não é uma particularidade da ficção de Bojunga (2011). Na vida real, tal qual Rachelle Bergstein (2013) reconhece, o sapato de salto, em determinados contextos, é uma forma de investir. A autora descreve uma cena em que "botas Loeffler Randall de pele de cobra, estonteantes com sua textura de manchas pretas, brancas e cinzentas; o bico curvado; 'arco' inclinado que terminava no salto muito alto e de largura média" (BERGSTEIN, 2013, p. 05) pareciam "perseguir" Pâmela; uma mulher que reconhecia que o valor das botas era "basicamente o valor do meu aluguel. Mas... [...] O aluguel garante meu apartamento por um mês, apenas. [...] essas (as botas), eu terei para sempre" (BERGSTEIN, 2013, p. 05). Uma justificativa que, segundo Bergstein (2013), a própria Pâmela sabia que era muito contestável, porém "sapatos bonitos parecem provocar esse tipo de pensamento criativo" (BERGSTEIN, 2013, p. 05).

Assim como Kristen "uma desenhista de moda e acessórios em início de carreira, bebia café gelado de US\$2, dinheiro que nem devia gastar” (BERGSTEIN, 2013, p. 05) comentava estar pensando "em investir em um par de Christian Louboutin [...]. - Talvez não um novo, mas [...] pares seminovos no eBay" (BERGSTEIN, 2013, p. 05). Adquirir esses sapatos estava fora do alcance financeiro de Kristen de qualquer maneira. No entanto "ela considera o valor daquela aquisição segundo critérios não exatamente monetários" 
(BERGSTEIN, 2013, p. 05) e afirmava que: "quando saio com eles, quero que as pessoas vejam estes saltos. Estou cansada de não ser levada a sério" (BERGSTEIN, 2013, p. 06). Bergstein reforça:

[...] a ideia de sapatos como investimento, uma moeda social, não é nova e remonta aos teatros da Grécia antiga, nos quais personagens de maior importância usavam sapatos de salto alto; às cortes de Luís XIV no século XVIII, onde foi decretado que apenas os homens do alto poder podiam calçar mocassins de salto vermelho e quadrado; aos Sioux do século XIX, em cujas tribos só era permitido aos chefes adotar certos padrões elaborados de contas na sola de seus mocassins de couro macio (BERGSTEIN, 2013, p. 06).

Adquirir essa peça para compor o figurino equivale na realidade ou na ficção a escolhas alusivas ao desejo de cada um(a) em relação ao meio de convivência. Para Inês, que não gozava de privilegiada condição social, seus sapatos não eram colocados como um investimento financeiro, mas como desejo relacionado ao sentimento de poder. Seu prazer em usá-los é o seu investimento, ela ama sapatos de salto, chega à casa feliz e já calçada com aquele salto preto de verniz, atitude que causa espanto em sua mãe: "-que tanto salto é esse, menina ?!” (BOJUNGA, 2011, p. 120), ao que prontamente Inês responde: “- Menina não, senhora! menina não usa sapato assim. - Foi dançar na frente do espelho, pra se admirar em cima do salto. - Agora sim, sou mulher" (BOJUNGA, 2011, p. 120). Inês se "emancipa" ao subir no salto bem alto que conquistou e por isso diz não ser mais menina. Agora, no alto daquele salto, Inesinha diz se tornar mulher. A mãe questiona "- pra que outro sapato, Inesinha?!” e Inês replica: “- O salto deste é diferente, dona Gracinha” (BOJUNGA, 2011, p. 120). Em seguida a menina “- Sentou, cruzou uma perna na outra, balançou o pé: - Não é lindo? Acho sapato de salto a coisa mais linda que existe. [...]" (BOJUNGA, 2011, p. 121).

Erguidas em um sapato de salto, como afirma Linda O'Keeffe (2008), as mulheres "são atrizes. Psicologicamente, os saltos altos permitem-lhes comandar e não ser comandadas. Uma mulher comum torna-se uma torre de sedução, olhando os homens literalmente de cima para baixo" (O’KEEFFE, 2008, p. 72). Além disso, "sexualmente, quer ela o reconheça, quer não, pode escolher tornar-se o sujeito ou o objeto de adoração masculina" (O'KEEFFE, 2008, p. 72-73) e no que se refere a "fisicamente, é impossível uma mulher acobardar-se quando está de saltos altos", pois nessa postura ela

é forçada a tomar uma posição, a ter uma pose, porque anatomicamente o seu centro de gravidade foi deslocado para diante. A parte inferior das costas arqueia-se, a coluna e as pernas parecem alongar-se e o peito é lançado para 
a frente. A barriga das pernas e os tornozelos parecem mais bem torneados e a curvatura inferior dos pés parece querer elevar-se dos sapatos (O'KEEFFE, 2008, p. 73).

Essa postura de controle projeta-se em Inês por meio das memórias, porque a mulher que ela é agora, ao rememorar seu primeiro sapato, revive a imagem de sua mãe intrigada com as atitudes da filha: "- não tô te reconhecendo, Inesinha! Cada vez o salto é mais alto, e a cara é mais pintada, e a blusa mais decotada!” (BOJUNGA, 2011, p. 124). A menina não respondia quando a mãe lhe indagava "com quem que tu tá te metendo? Por onde tu tá te enfiando? E tu só faz é rir quando eu falo..." (BOJUNGA, 2011, p. 124). Inesinha apenas ria elevada sobre os saltos altos que obrigam seus pés "a assumir a postura vertical descrita pelo estudioso do Sexo A. Kinsey como a posição feminina típica durante a excitação sexual" (O’KEEFFE, 2008, p. 73), postura possivelmente conveniente para Inês que, naquela época, “já estava enredada numa vida que tinha que ser mantida em segredo [...]” (BOJUNGA, 2011, p. 124) de sua mãe.

Vagueando sem sono, a memória da personagem aparenta orientar-se pelos sapatos conquistados ao longo da vida, as cenas são rememoradas a partir dos saltos usados, as reminiscências de Inês vinculam-se a cada salto conquistado por ela. No estado de vigília em que se encontrava no episódio, ela vagueia pela memória e recorda seu primeiro sapato de salto, em meio a "[...] outros sapatos... sandálias... chinelos... até se deter numa sandália vermelha de salto estilete que tinha uma flor aplicada na altura do peito do pé [...]" (BOJUNGA, 2011, p. 125). As lembranças que Inês carrega dessa última sandália de salto reforçam a importância conferida à peça em sua vida. “Ah!... ela tava usando a sandália naquele dia... quando foi visitar a dona Gracinha... e no portão de ferro o segurança disse que já fazia muito tempo que a dona Gracinha não morava mais no casarão..." (BOJUNGA, 2011, p. 125). Ao relembrar sua história, quando ainda era jovem - esperançosa de uma vida com menos necessidade financeira - sua mente relaciona a visita à mãe - que não via há muito tempo - ao uso da sandália, sobre a qual Inês relembra inclusive detalhes como cor e ornamentação, associados ao sentimento de fracasso por não ter conseguido reencontrar sua progenitora naquele momento.

Este tipo de salto que a personagem de Bojunga (2011) relaciona à visita à mãe, o salto agulha, foi criado, conforme registra Bergstein (2013), na Europa no início da década de 1950, denominado stiletto ou estilete - referência a um tipo de faca com a lâmina muito fina; esse salto nasce como uma inovação pertinente das extravagâncias do pós-guerra. "Diferente da sólida e confiável anabela, o salto agulha exercia grande pressão sobre a parte dianteira e 
inferior do pé de uma mulher, o que a afastava muito do calçado ideal para caminhar" (BERGSTEIN, 2013, p. 67). Mas, segundo ironicamente sugere essa mesma autora, após aquele período de escassez e aquisições mais funcionais, "as mulheres estavam prontas para adotar estilos que significassem ideais novos: sex appeal, status e luxo. O salto agulha era um tipo novo de sapato justamente por ter se afastado com tanta nitidez de sua função" (BERGSTEIN, 2013, p. 67). Esse sapato representava pouco conforto. Era pontudo, o salto bastante alto e fino, tal estrutura dificultava a locomoção, porém tornou-se objeto de desejo feminino, ao que Bergstein (2013) argumenta:

Como um carro ou um anel de diamante, o salto agulha era eficiente ao classificar as mulheres de acordo com a posição econômica e o valor social. Se uma mulher não conseguia andar em cima dos delicados e vertiginosos sapatos, então, ela não havia conquistado o direito de usá-lo. Se uma mulher não podia se dar ao luxo de não ficar em pé, então, desculpa, querida - salto agulha não era para ela (BERGSTEIN, 2013, p. 68).

Apesar de mulheres de classes média e alta, no período da Guerra, terem trabalhado juntas em prol da economia, Bergstein (2013) recorda que, ao final da segunda Grande Guerra, a moda acentuou os estratos sociais. Usar saltos nada funcionais requeria da mulher disponibilidade, tempo para caprichos, além de posses. A mesma pesquisadora compara esse estilo de calçado ao chopine europeu dos séculos XIV a XVII e ao "pé de lótus" Chinês. Ambos representavam "sinal de liberdade do trabalho manual [...] e conotações sexuais" (BERGSTEIN, 2013, p. 69) e, ainda que o salto agulha, obviamente, seja percebido como "menos extremo que o oriental pé de lótus ou os ocidentais chopines, continha ecos dessas modas históricas no sentido de convidarem as mulheres a priorizar estilo sobre mobilidade" (BERGSTEIN, 2013, p. 70). O salto agulha emerge em um momento no qual as mulheres são "expulsas da força de trabalho com a mesma facilidade com que haviam sido chamadas a integrá-la por patriotismo" (BERGSTEIN, 2013, p. 71). Esse estilo de salto foi produzido "para ser um prazer, não uma utilidade: um sinal de que as mulheres nos anos pós-guerra podiam pôr os pés para cima e satisfazer seus caprichos" (BERGSTEIN, 2013, p. 71), uma possível persuasão no processo de retorno dessas mulheres para a vida privada.

Devido à pouca funcionalidade desse salto, usá-lo cotidianamente seria algo incongruente para Inês. Ela, apesar de mostrar em todos os episódios uma postura confortável em cima dos saltos, não é detentora de posses, tampouco pertence ao alto estrato social. Inês não dispõe de condições financeiras para prostrar-se. Ela precisa de trabalho para garantir seu sustento. Ao contrário das usuárias do salto agulha do pós-guerra, Inês é oriunda de família 
humilde, é filha da pobreza. O uso dos saltos para essa mulher não denota luxo, riqueza. Aqueles saltos que vestiram muitas mulheres afortunadas na realidade - mesmo oprimidas por eles - não calçam, na ficção de Bojunga (2011), Inês sob a égide de motivos semelhantes. Para esta, a prostituição apresentou-se como possibilidade de sair da pobreza; um deslumbre num impulso juvenil que culmina em sofrimento de estar sob o jugo de seu algoz, seu agenciador e, com o passar do tempo, no abandono clandestino daquele espaço de violência ao qual esteve submetida.

A luxúria da prostituição leva a jovem Inês a fazer uso dos saltos - opressores dos pés e dos comportamentos das mulheres ao longo da trajetória de vida delas na ficção e para além dela. Contudo, são eles também que auxiliam a personagem de Bojunga (2011) a dissimular a opressão vivida. Ela não usa o salto para permanecer estática na vida privada e longe da vida pública. Ao contrário, mesmo sob o domínio masculino, Inês sente-se no comando da situação por meio do uso da sexualidade, da sensualidade, da sedução. E quando isso se esvai, ela foge do seu explorador para (re)construir sua família com a mãe e a sobrinha. Inês, que é oriunda da escassez financeira, compreende as várias formas de opressão que se entrelaçam à relação de gênero, e em função disso sobe em seus saltos bem altos à procura de romper com aquela camada social de que fazia parte, para transformar o salto numa representação de sua ascensão social.

\section{OS MESMOS SALTOS, OUTROS PÉS}

Na narrativa de Bojunga (2011), a felicidade de Sabrina se esvai quando sua tia é assassinada pelo ex-cafetão. Esse momento deixa a menina desamparada. Ela vê diante de si apenas a opção que herdou da tia: os sapatos de salto bem altos, que lhe serviam perfeitamente e que seriam usados para sustentar a si e sua vó Gracinha. E são os olhos do amigo Andrea Dória que nos fornecem a imagem da menina, sobre um salto muito alto, adentrando o matagal denso com o açougueiro. Ainda ao longe, o rapaz "viu o pé dela calçado num sapato abotinado de salto bem alto, tal qual o sapato que a Inês usava pra dançar" (BOJUNGA, 2011, p. 163), o que fazia a menina aparentar mais idade para possibilitar agenciar-se na prostituição.

O amigo permaneceu sorrateiro, mantendo a distância, durante tempo suficiente para ver Sabrina sair do mato e sentar na beira do rio: "vê ela tirar o sapato de salto e guardar o dinheiro nele; vê ela assim, descalça, balançando as pernas, depois se inclinando pra tentar alcançar a água com a ponta do pé”. (BOJUNGA, 2011, p. 168). A cena observada por Andrea 
Dória apresenta o calçado de Inês, agora, na posse de Sabrina como o elemento condutor da sobrevivência dessa menina, é esse legado deixado pela tia que favorece a paga pelo corpo da garota que descalça os pés imediatamente ao término do encontro.

Nesse mesmo episódio, os dois conversam e Sabrina revela ao amigo parte da história que ela crê ser da mãe e o encara com um semblante desafiador quando diz: “- ela também era puta. Assim que nem eu [...]. Sabia que eu sou puta? - ela insistiu. Deu de ombros. - Se não sabia ficou sabendo, não é?” (BOJUNGA, 2011, p. 170) mostrando estar ciente da sua condição. Mas mesmo com Andrea Doria enfatizando a idade da menina como inapropriada para ser uma prostituta, ela reage sob a afirmativa de que: “- Eu sou, ué! [...]. Eu vim aqui pra deitar com ele. Porque ele disse que esse matagal aí é melhor lugar pra ninguém ver; disse que se ele fosse lá em casa a vizinhança ia saber [...]” (BOJUNGA, 2011, p. 171). Ela temia a intromissão da vizinhança na vida dela e da avó e confessa preferir o suicídio a precisar voltar para o orfanato e voltar a não ter família. Afirmação que sugere ter sido aquela vida bastante lastimável para Sabrina.

Todo o diálogo das duas personagens enfatiza como Sabrina, apesar da pouca idade, possui discernimento da sua condição marginalizada. A garota se sente como o pilar da família e o dinheiro é imprescindível para a sua independência e a da avó e, sobretudo, é a maneira de poderem ficar juntas, formando um lar, como Sabrina sempre desejou. Essa convicção se reflete no uso do sapato de salto para se tornar "mulher". No diálogo abaixo, com Andrea Doria, a menina revela que sua tia usava o sapato também para guardar dinheiro:

- Ela fazia assim com tudo que é sapato e sandália e chinelo que ela tinha. Ela tinha uma porção. Pra roupa ela não ligava muito. A mania dela era com o pé. Mal comprava o sapato, descolava logo a palmilha... depois colava a ponta de novo. Depois que [...] eu fui saber dela onde a gente comprava sandália com grana dentro e ela morreu de rir. E aí ela me contou que sapato era o cofre dela (BOJUNGA, 2011, p. 173-174).

A partir da morte da tia, Sabrina precisou recorrer ao "cofre" diversas vezes, descolando cada sola de sapato de Inês e ao fim de um mês, esgotou-se também essa reserva financeira e "agora não precisa mais contar" (BOJUNGA, 2011, p. 174). Tornou-se tarefa da menina, então, cuidar da avó senil e conservar a família para não precisar voltar mais para o orfanato, tampouco deixar dona Gracinha em um sanatório como sugeriram alguns vizinhos.

Sabrina reproduz atitudes da tia, dada a sua responsabilidade agora. Ela "pegou o sapato, enfiou uma nota de dez debaixo da palmilha e a outra escondeu no decote da blusa. Falou como se estivesse sozinha: - Tenho que ir lá no super: a vó Gracinha tá querendo leite, 
batata e pão. - Calçou o cofre" (BOJUNGA, 2011, p. 174). Andrea Doria indaga se há algum dinheiro em outro lugar além das palmilhas, numa poupança, num banco. Sabrina é ligeira ao responder que "- a poupança da tia Inês tava aqui. - Bateu no sapato. - Mas acabou rapidinho, a gente teve que pagar um montão de coisas na hora de enterrar ela" (BOJUNGA, 2011, p. 175). Mais do que isso, "no dia seguinte chegou a dona da casa dizendo que pra gente continuar morando lá tinha que pagar um mês adiantado; [...] ficou de mão estendida dizendo que se eu não pagava um mês adiantado ela botava a gente pra fora" (BOJUNGA, 2011, p. 175). Como ficou com medo do despejo, foi ao quarto da Inês e pegou o dinheiro que ainda restava "Quando é assim feito botinha cabe mais nota dentro. A tia Inês tinha tanta mania de sapato que eu achei que a grana ia durar muito tempo [...] - Só que acabou” (BOJUNGA, 2011, p. 175).

Num outro episódio em que Andrea Doria e seu tio Leonardo dialogam sobre Sabrina, o enredo confirma o salto como elemento oportuno para travestir a menina em uma mulher. $\mathrm{O}$ tio do rapaz atribui ao tamanho do salto da menina a capacidade desse calçado modificá-la, proporcionando um "amadurecimento" de sua aparência:

- Mas ela não é assim tão garotinha, é?

- É, sim, ela ainda vai fazer onze anos. Hoje ela tava parecendo mais velha por causa do sapato que ela tava usando. Deu uma crescida!

- Que saltão, hein?

- Nossa! não sei como é que ela aguenta andar em cima daquilo tudo. Era da tia dela.

- Mas parecia justo no pé.

- Elas calçavam igual. - Foi se recostando no banco. - Não pensei que você fosse prestar atenção no pé dela.

- É difícil a gente não prestar atenção nela toda.

- Por quê?

- Você deve saber melhor do que eu.

$-\mathrm{Eu}$ ?

- Vocês não são amigos?

- Não. Quer dizer, amigo-amigo a gente só começou a ficar hoje.

$-\mathrm{Ah}$, é?

- Antes era só uma coisa assim... uma coisa só pra dançar. (BOJUNGA, 2011, p. 183).

Usar saltos altos de outra pessoa para alterar a idade é demonstrado já no século passado na obra Ana de salto alto de Sérgio Caparelli (1981). No conto homônimo - por meio de um narrador em terceira pessoa - tomamos conhecimento de que Ana, num dia sozinha e entediada em casa, começa a se maquiar utilizando os cosméticos de sua mãe. A menina faz penteado, coloca um vestido novo de festa e para completar o figurino calça um dos saltos de sua mãe que tinha "um pé tão pequeno. Do tamanho do seu" (CAPARELLI, 1981, p. 24-25). 
Ao circular pelas ruas, a personagem de Caparelli (1981) repara que "um rapaz muito moço [...] não desgrudou dela o olhar em nenhum instante. [...] - Sabe que você é muito bonita! disse o rapaz" (CAPARELLI, 1981, p. 26). A menina "ficou desorientada, sem saber se agradecia ou não ao cumprimento. Saiu apressada [...]” (CAPARELLI, 1981, p. 26). Mais à frente, em umas vitrines "olhou para o manequim do outro canto e ele the piscou. Assustou-se [...], ficou nervosa. Olhou de esguelha. Continuava a piscar. Assustada, deixou o lugar" (CAPARELLI, 1981, p. 27) rapidamente. Parou para tomar um sorvete, pediu ao garçom um de chocolate - levava uma bolsa da mãe com algumas moedas tiradas de um cofrinho - "o moço não demonstrou haver nenhuma diferença entre ela e as outras moças que comiam sorvete de chocolate na mesa mais adiante" (CAPARELLI, 1981, p. 27). Após pagar a conta, quando já estava de saída ouviu do rapaz: "- seu troco, mocinha. Aquele "mocinha" dispensava qualquer troco. Que ficasse com ele, como gorjeta" (CAPARELLI, 1981, p. 28). Preocupada com o horário de chegada da mãe, retorna depressa para casa, “[...] alguns rapazes lhe dirigiam gracinha. Ela gostava, mas punha uma cara feia, para se fazer respeitar" (CAPARELLI, 1981, p. 28).

As personagens Sabrina, de Bojunga (2011) e Ana, de Caparelli (1981), a despeito de estarem distantes uma da outra na localização temporal e discreparem nos motivos de uso do salto, convergem no que tange à adulteração da idade por intermédio de maquiagens e principalmente dos sapatos de salto. Ambas usam calçados emprestados de mulheres parentes adultas, cujos pés são bastante pequenos, servindo seus sapatos perfeitamente os pés das meninas. As duas personagens, produzidas com o novo figurino, garantem galanteios de homens mais velhos; ao final dos preparativos, Ana se enxerga mais velha e reconhece que os demais também o farão. Sabrina também se vê assim, mas carrega os motivos muito mais complexos ao precisar subir no sapato de salto, tendo em vista que para ela, mais do que não parecer mais criança, o salto alto - bem alto - favorece a ela a postura de responsável pelo lar, pela continuidade da família que lhe foi negada noutro tempo, mas, agora, apesar da perda da tia, pensava ser possível assegurar com os recursos financeiros adquiridos com seu trabalho.

Sabrina, que também vivia um momento de esperança com a construção de uma família, assiste - com a morte da tia - a destruição de seus sonhos antes mesmo de conseguir aproveitar o aconchego daquele lar. Embora a morte de Inês configure a ruptura com a felicidade da menina, esta não é testemunha passiva a esse cenário, porque utiliza as armas que a própria vida lhe concedeu até ali e se prostitui para sobreviver com independência na condição em que se encontrava. Tia e sobrinha calçavam idêntico: as mazelas, os abusos, os maus tratos, as desgraças todas que acompanharam a trajetória de cada uma dessas 
personagens se assemelham. A pobreza e a marginalização a que são relegadas na vida se equivalem. O sapato de salto é o legado que Inês deixa para a sobrinha; é uma representação simbólica de tudo que dele é possível extrair. Dado que, seja nos pés de uma ou de outra, o sapato de salto mantém a esperança de uma vida proeminente.

\section{PÉS NO CHÃO}

A partir de uma linguagem fluida e de um contexto verossímil, a narrativa de Bojunga (2011) favorece ponderar a respeito da marginalização a que estão relegadas muitas mulheres em razão de sua condição social e, principalmente, entrelaçado a isso, propicia reflexões sobre os percalços enfrentados por mulheres para garantia da sobrevivência nesta sociedade, cuja característica patriarcal se baseia em discursos de dominação machistas e misóginos.

A trama percorre histórias que se cruzam. Todas motivadas por conflitos relacionados ao patriarcado que afligem outras personagens mulheres que, tal qual Inês e Sabrina, vivem subjugadas pela representação masculina em suas vidas. Das duas personagens analisadas, temos tia Inês, que, ainda jovem, adentrou no mundo da prostituição, cujo resultado - ao resolver se afastar - foi seu assassinato (um reflexo da dominação de seu ex-agenciador, que considerava Inês sua propriedade) e Sabrina que, quando criança, foi vítima de violência, violação, abusos e assédios praticados por homens adultos.

Ao observarmos os pés dessas duas personagens, identificamos possibilidades de enfrentamento do sistema patriarcal pelo uso deste elemento em comum: o sapato. Como vimos, ele é um grande influenciador da moda e dos modos de ser e estar no mundo real ou ficcional, levando mulheres ao paradoxo entre a sensação de prazer e sofrimento. Por isso, cogitar essa peça como elemento de subversão feminina na narrativa de Bojunga (2011) requer a percepção das entrelinhas, do subentendido, do não dito, porque só assim é possível perceber a internalização e naturalização de regras que manifestam a dominação de homens sobre mulheres na sociedade narrada por Bojunga (2011) ou nesta em que vivemos.

Reforçamos, por fim, que em nossa análise o sapato de salto, essa peça principal na composição do vestuário, representa - na vida e na ficção - muitas opressões, subjugações femininas. Por outro lado, imprime - como vimos também nas personagens Sabrina e Inês - a dissimulação, a expressão da própria sensualidade, o realce da luxúria, práticas que em determinadas situações se fizeram necessárias para a sobrevivência de ambas. Tia e sobrinha, marginalizadas pela condição de pobreza em que se viam, cada uma em seu tempo, resistem alicerçadas em seus saltos bem altos, numa aspiração por melhores condições de vida. A obra 
de Bojunga (2011), destinada ao público de leitores e leitoras juvenis, permite uma leitura prazerosa aos meninos e às meninas dessa faixa etária. Com o uso da verossimilhança e de uma escrita alegórica, a aparente resolução dos infortúnios das personagens é sinônimo de que as rupturas com a dominação - também na realidade - são realmente possíveis.

\section{REFERÊNCIAS}

ANDERSEN, Hans Christian. Os sapatinhos vermelhos. 1849. Disponível em: http://aguasdeprata.blogspot.com.br/2012/11/os-sapatinhos-vermelhos-por-hans.html. Acesso em: 22 mar. 2020.

BANDEIRA, Pedro. O Fantástico mistério de Feiurinha. 3. ed. São Paulo: Moderna, 2009.

BEAUVOIR, Simone de. Segundo Sexo: fatos e mitos. Tradução de Sérgio Milliet. 4. ed. São Paulo: Difusão Europeia do Livro, 1970. Disponível em: https://docero.com.br/doc/nnsvv50. Acesso em: 01 abril. 2020.

BERGSTEIN, Rachelle. Do tornozelo para baixo: a história dos sapatos e como eles definem as mulheres. Rio de Janeiro: Casa da Palavra, 2013.

BOJUNGA, Lygia. Sapato de salto. 2. ed. Rio de Janeiro: Casa Bojunga, 2011.

CAPARELLI, Sérgio. Ana de salto alto. Porto Alegre: L\&PM Editores, 1981.

CUNHA, Jurema Alcides. Dicionário de termos de psicanálise de Freud. Porto Alegre: Globo, 1970.

KURY, Adriano da Gama. Minidicionário Gama Kury da Língua Portuguesa. São Paulo: FTD, 2001.

O'KEEFFE, Linda. Sapatos: uma festa de sapatos de salto, sandálias, botas. Edição Portuguesa: H.F. Ullmann, 2008.

ORTHOF, Sylvia. Uxa ora fada, ora bruxa. 8. ed. Rio de Janeiro: Nova Fronteira, 2012. SONEGHET, Marilena. Trança. Vitória: Projeto Nosso Livro, 2012. 